\title{
都市内部における企業本社の分布について
}

一地方の 5 都市を例として—

吉田宏

口企業（本社）が都市に集中していることは， すでに明らかである。しかしそれが，都市域内 部でどのような分布現象を有するのか実態に関 する考察は従来きわめて少なく(板倉 1965)，そ れも東京に関する報告が若干見られるに過きな (、1)。そして服部 (1964aａ，b) らによる東京での 研究では，本社の分布は都心を核とし，周辺に かなり分散した集在型分布を示すこと，また巨 大企業の本社ほど都心地区への集心性を高める こと等が明らかにされている。

この小稿では, 巨大都市ではない, 地方都市 をえらび，その規模が異なる場合，比較的規模 の大きい企業の本社はそれら都市内部に扒いて どのような分布構造を示すかを, 本社数・産業 構成・資本金階級規模を指標に検討し，もって 都市の地域構造を解明するための資料とした い。

なお，5市の対比の都合上，当該各市に中心 地点を定め2), その中心地点から半径 $1 \mathrm{~km}$ 間 隔の同心円を描いて単位地区（IＶII）を設定 した。（1）調查対象都市は, 仙台・宇都宮・水
戸・米沢・白河の5 市。(2) 企業本社は, 1966 年 7 月 1 日実施の事業所統計調查結果から, 資 本金 1 千万円以上のものを対象とした。（3）各 都市内部に批ける本社の位置の確訆は，それそ れの「住宅地図」(1969) による。

\section{1 調查対象本社の概観}

当該 5 市に批ける資本金 1 千万円以上の企業 本社数は第 1 表のこととで，その数は都市規模 が大になるにつれ等比数列的に增加し，かつそ の规模別構成子異なる。各企業の資本金額を， 事業所統計に準してて $a \sim f$ の 6 階級に分けて都 市別にみると，仙台には50 億円以上 a をはじ め 6 階級の総てが存するが, 宇都宮は $\mathrm{a} \cdot \mathrm{b}(10$ 檍円以上）がなく，水戸は a のみがない。そし

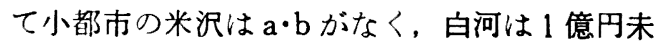
満の企業にとどまる。そこで，資本金 1 億間以 上の企業を仮りに大企業とし, 各市の企業本社 数（資本金１千万円以上）に占めるその割合をみ ると，仙台 $10.7 \%$ (实数 28) - 宇都宮 $4.7 \%$ (6) ・水戸 $6 \%$ (5)・米沢はその絶刘数当少ないこ

第 1 表 5 市の盗本金階級別企莱本社

(1969)

\begin{tabular}{|c|c|c|c|c|c|c|c|c|c|c|}
\hline & 盗本金階 級 & 仙 & 台 & 宇 都 宫 & 水 & 戸 & 米 & 沢 & 白 & 河 \\
\hline $\begin{array}{l}a \\
b \\
c \\
d \\
\text { e } \\
f\end{array}$ & 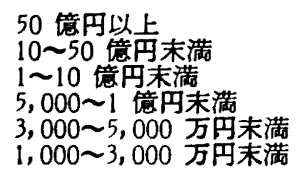 & $\begin{array}{r}2 \\
1 \\
25 \\
22 \\
32 \\
180\end{array}$ & $\left(\begin{array}{r}0.8) \\
0.4) \\
9.5) \\
8.4) \\
(2.2) \\
68.7\end{array}\right)$ & 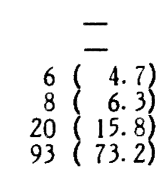 & $\begin{array}{r}1 \\
4 \\
3 \\
13 \\
62\end{array}$ & $\begin{array}{r}- \\
1.2 \\
4.8 \\
3.6 \\
15.7 \\
74.7\end{array}$ & $\begin{array}{r}2 \\
2 \\
2 \\
27\end{array}$ & $\begin{array}{l}- \\
6.1) \\
6.1) \\
61.1 \\
81.7)\end{array}$ & & (14.3) \\
\hline & 計 & 262 & $(100.0)$ & $127(100.0)$ & 831 & 100.0) & 331 & 100.0) & & 00.0) \\
\hline
\end{tabular}

（）内数植は各市の輠成比\%

1) 木内（1951）の研究にみられることく，多くは行政区域単位で捉えたものであり，詳細なりのてはない． その点, 服部 (1964b，1967）は分布の実態をメッシュ・トット・等値線等で表現している.

2）中心地点を都市内部の何処に定めるか加容易てない。簡便な方法の一つに，路線価の最高地点を中心地 点とすることも行なわれるか，必ずしも妥当なものとはいえない，何故なら，影・土地利用から中心 地と訆定しがたい駅前（例，仙合・承戸）などに檑端に高い評価類が出ること，およびその評定にはあ る程度投機的な比更が加わっており，局所毎にみられる場合には，路線価格の利用は道切でない（杉 村 1965)。從って本穗ては，森川 (1966）が指墒した路線価と土地利用の関保を考虑して，5市の中心地 点を設定した.なお，この点に関しては，小笠原節夫氏の御助言をいただいたことを付記しておきたい。 
とから 6.1\% (2)・白河 0 となる。つまり, 当 該 5 市に扰ける資本金 1 千万円以上の地元企業 の内, その 89\%以上 (白河は 100\%) が 1 億末満 の企業で占められ，いわゆる大企業本社の存立 は仙台などの若干数を除けば，きわめて僅かな ものでしかない。またこれら大企業が各産業 部門内で占めるウェイトは，金融保険業・サー ビス業・運輸業，そして電気ガス業3)で高い。 建設業・商業は企業本社そのものは多いが, こ れらは不動産業をも含めて，資本金階級 $\mathrm{f}$ の占 める割合が他産業に比して高く、いわゆる弱小 企業の多い産業部門となっている。

産業構成からみると(第2 表)，仙台には8 産 業, 宇都宮・水戸は 7 産業，そして米沢・白河 が 4 産業となり，都市規模が大になるにつれ企 業本社数および産業の種類も增加する。都市間 で産業構成比は異なるが仙台・宇都宮・水戸で は商業4)のウェイトが最も高く、3市の企業本 社全体のそれぞれ 43\%・47\%・56\%を占め, 次いで製造業・建設業・サービス業の序列とな る。だが，米沢・白河ではその絶対数も少ない ため異なった構成比を示し，製造業のウェイト はかなり高いが，金融保險業・不動産業そして 商業 (白河のみ) は欠ける。

\section{2 考察}

（1）単位地区別の分布および状態

各都市の中心地から半径 $1 \mathrm{~km}$ の同心円を描 いてそれそれの単位地区を設定し，地区別に本 社数をみると第 1 図のことき結果となる。すな わち，各市とも中心地区のIに最も高い集積か みられ，外周の II ・III・IV……向かって漸

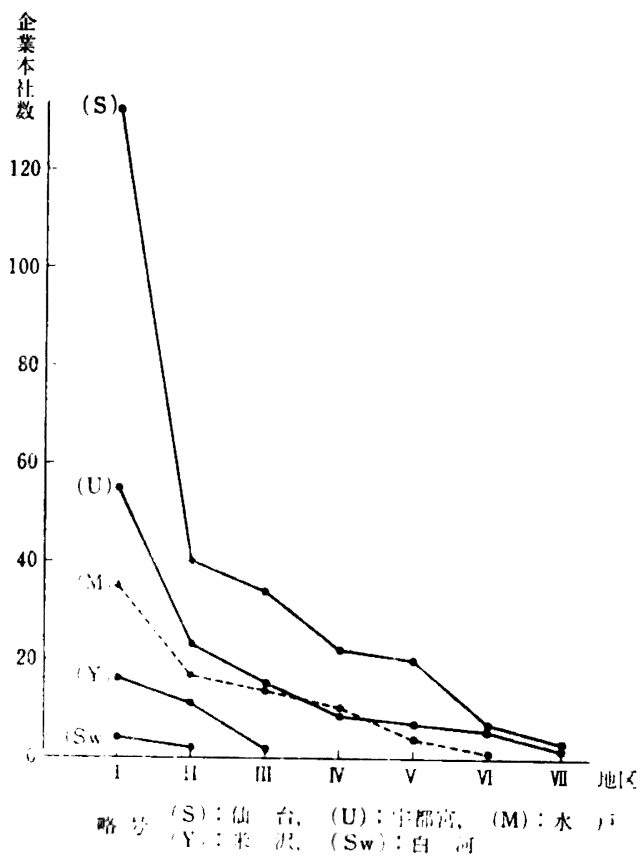

第 1 四 5市の地区別本社数

減する。地区Iに集積している本社の割合は, 各都市企業本社総数のおよそ 40～50\% 台を占 め,かなり集在性の高いことが分かる。ただ 都市の米沢・白河では，その絶対数も少なく分 布の筑用も狭いためI の割合が高くなってい る。それに比し，仙台・宇都宮・水戸の3市で は，都市規模が大きい、ど中心地区 I へのウェ イトを高め,かつ外周との恭離が大きい。この ことは都市規模が增大するにつれ中心地におけ

第 2 表 5 市の産菜分類別企業本社

(1969)

\begin{tabular}{|c|c|c|c|c|c|c|c|c|c|c|}
\hline 産業大分類 & 仙 & 合 & 宇 都 & 宫 & 水 & 戸 & 米 & 沢 & 白 & 河 \\
\hline 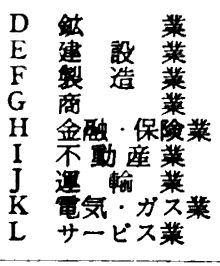 & $\begin{array}{r}36 \\
51 \\
115 \\
5 \\
9 \\
24 \\
2 \\
20\end{array}$ & $\begin{array}{l}- \\
13.7) \\
19.5 \\
43.9 \\
1.9 \\
3.4 \\
9.2 \\
0.8 \\
7.6\end{array}$ & $\left.\begin{array}{r}14 \\
31 \\
60 \\
3 \\
3 \\
11\end{array}\right\}$ & $\begin{array}{r}11.0) \\
24.4 \\
47.2 \\
2.4 \\
2.4 \\
8.7 \\
-3.9) \\
37\end{array}$ & $\begin{array}{r}1 \\
10 \\
12 \\
47 \\
3 \\
6 \\
4\end{array}$ & $\begin{array}{r}1.2) \\
12.1 \\
14.5 \\
56.6 \\
3.6) \\
-7.2) \\
4.8)\end{array}$ & $\begin{array}{l}1 \\
17 \\
13 \\
\\
2\end{array}$ & $\left.\begin{array}{c}- \\
3.0 \\
51.5 \\
39.4\end{array}\right)$ & & $\begin{array}{l}(\overline{28.6}) \\
42.8) \\
- \\
\overline{-} \\
\left(\begin{array}{l}14.3 \\
14.3\end{array}\right) \\
-\end{array}$ \\
\hline 計 & 262 & $100.0)$ & $127(10$ & $00.0)$ & 83 & $100.0)$ & 33 & $100.0)$ & & $(100.0)$ \\
\hline
\end{tabular}

資本金 1 千万円以上. （）内数俇は标成比\%

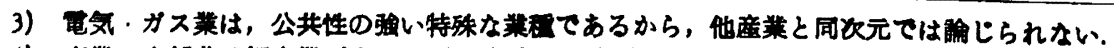

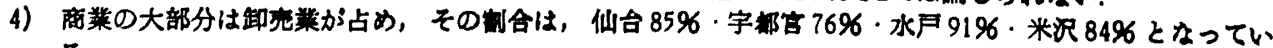
万. 
る本社の充填密度が高まり、いわゆる業務街 (CBD) としての性格が強まることの一面を示唆 している。地区II になると，仙台・宇都宮・ 水戸ではそれぞれの本社数の 15〜20\%を占め るが,この割合は都市規模が小になるにつれ若 干增大する。米沢・白河ではそれが 28〜33\% で更にウエイトが高まり，I と合わせて全体の 85〜90\%に達する。これは前述の理由による あのであり，業務街としての機能分化が進んで いることを意味しない。更に III より外周で は, 都市規模によって分布範围の広狭が明瞭と なり，米沢・白河ではII との較差がきわめて
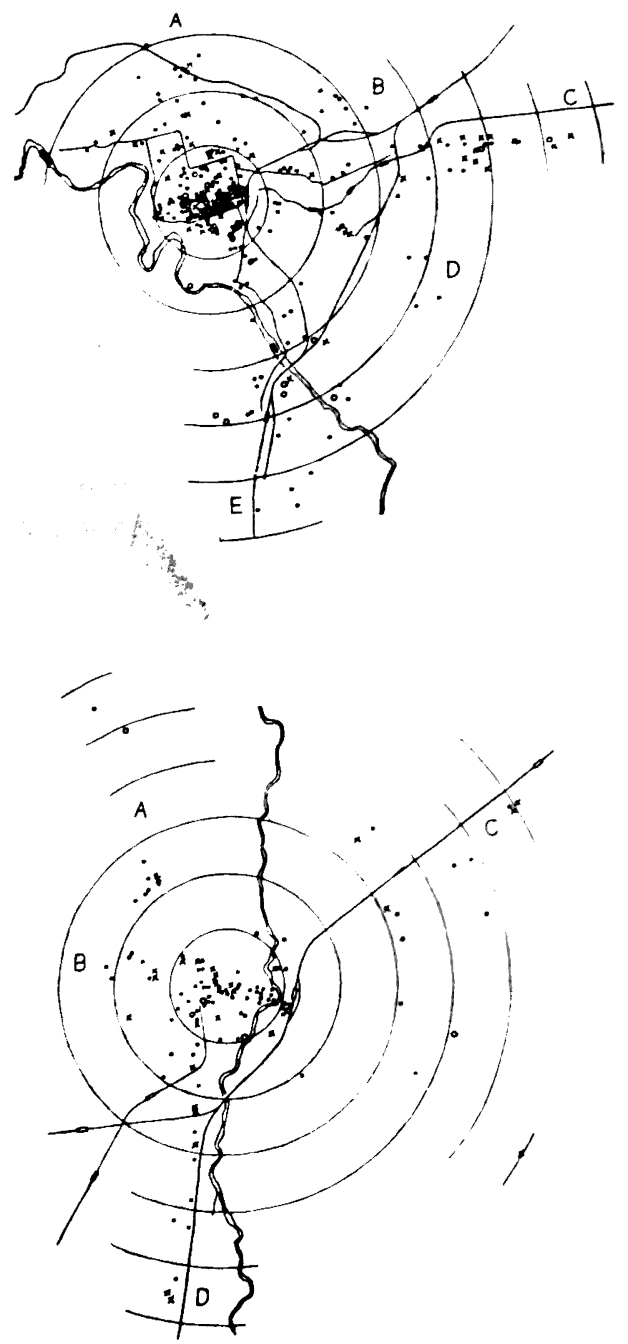

大きいのに対し，仙台など3市では漸減を示 す。

ところで今述べたことは，5市の対比の都合 上，便宜的に設定した単位地区での分析である から，それは分布の一面を概括的に捉えたこと にはなったとしても，実際の状態を説明したこ とにはならない。とくに分布の状態は，各市と も中心地区上りは外周八向って偏在が顕著とな るから (第之因)，この点の検討も必要である。 そこで以下は，主として外周に立地している本 社の分布状態を第 2 図を基に概観する。

[仙台]分布の広がりは中心地から $\mathrm{A} \sim \mathrm{E}$ の 5 方向にみられる。A：国道 4 号線沿いで北部 は北仙台駅一帯。B：小田原工業地区で製造業
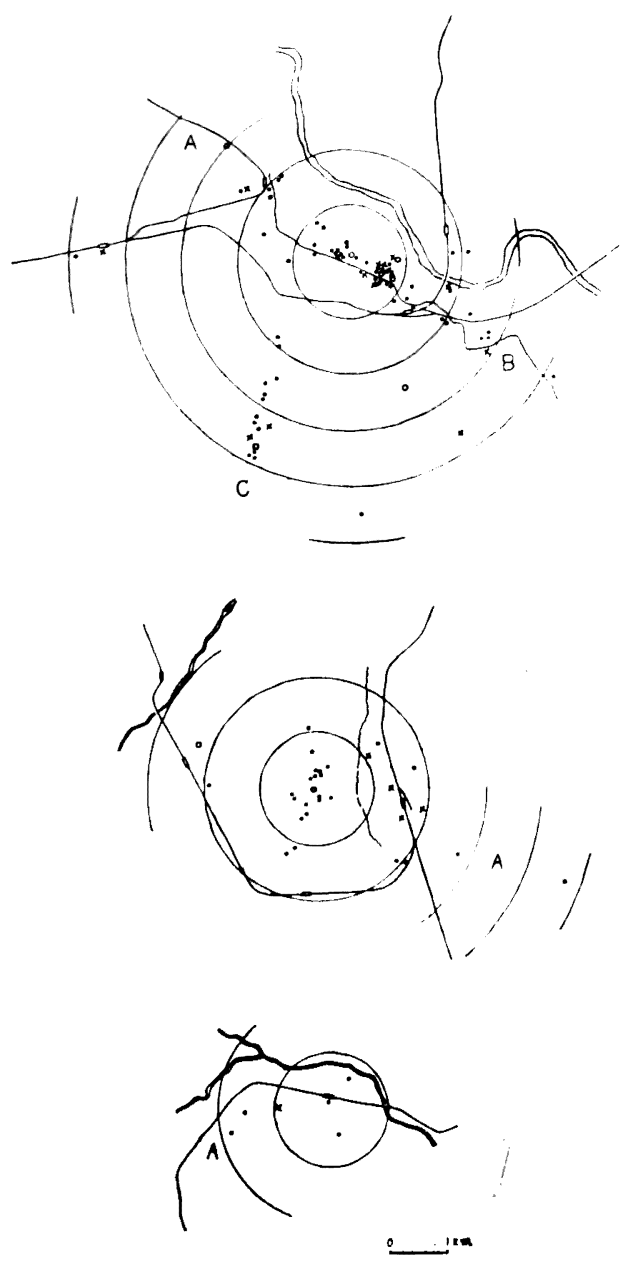

第2因企莱本社の分布

左上：仙合 左下：宇都宫 右上：水户 右中：米沢 右下：白河

○资本金 1 供円以上の本社

$\times$ 望本金 3,000万円〜1 億円未满の本社

- 本金 1,000万円 3,000 万円末満の本社 
が占める。C：国道 45 号線（仙塩街道）沿いの苦 竹地区が中心で，東端は福室地区に達する。業 種の大半は自動車ディーラー。 D：仙台駅東部 から宮城野貨物駅，そして荒井地区方向に分 布。卸売市場・運輸・製造業が分布する。 E : 国道 4 号線沿い扰よび長町駅 (操車場) 周辺一 帯で, 製造・運輸業が多い。

〔宇都宮〕 A D の 4 方向に分布が広がる。 A：国道 119 号線（日光街道）沿いの中戸祭地 区。B：大谷・鹿㳊両街道沿いの一ノ沢町地区。 $\mathrm{C}$ ：分散状態にあり，国道 4 号線・同ハイパス および1960年造成に着手した宇都宮工業団地一 帯 (平出地区)。D：国道 4 号沿線の上横田地区 を中心に分布, 南端圢篗宮駅付近に達する。上 横田地区はいずれも自動車ディラーが占める。

[水戸]市街地構造と幹線道路を軸として $\mathrm{A} \sim \mathrm{C}$ の 3 方向に分布寸る。 $\mathrm{A}$ ：国道 123 号線 沿いに，中心部から袴塚町までの範囲。 $\mathrm{B}$ ：国 道 51 号線沿線で谷田町まで分布がみられる。 C：国道 6 号線を軸とした千波地区で，業種の ほとんどが自動車ディーラーである。

[米沢・白河]両市とも企業 (本社) が僅かな ため，分布の状態は捉えにくい。ただ，米沢は 国道 13 号沿線の A 方向に, 白河も同 4 号線治 いに若干の分布の広がりがみられる。

以上のごとく，都市内部における本社の分布 状態は，その数の多宾によるのはもとより，そ れぞれの地形を反映した市街地構造・幹線道路 の配置・都市計画による用途地域の設定 ${ }^{5)}$ 等で 異なるが，とりわけ各市の外周部における分布 状態からも明らかなよらに, 幹線道路の役割が きわめて大きい。

まえに筆者 (1969) は，仙台を例に支店等事業 所の分布について調查し、それがかなり集心性 の高いことを指摘した。しかし地元企業の本社 の分布は，中心地区に高い集稓がみられながら も，幹線道路を枢軸に広範囲に分布する。それ は，支店の多々がオフィス業務であるのに対 し, 地元企業のはとんどは主として企業規模が 小さいために，本社と現業部門が同居の形をと るためであり,この点は各企業の業種 (業態)に よってその地域的分布が異なることからも察知 しえる。

\section{（2）産業分類からみた分布の状態}

都市内部における本社の分布状態は業態によ り一様ではない。中心地区 I への集積が高い業 種は, 都市規模で若干異なり, 仙台・宇都宮・ 水戸の 3 市では金融保険業 $\mathrm{H}$ ・商業 $\mathrm{G} ・$ サービ ス業 $\mathrm{L} ・$ 不動産業 I 等となる。これら 4 産業が 上記 3 市の地区 I に占める構成比は, 仙台が $\mathrm{H}=80 \% \cdot \mathrm{G}=64 \% \cdot \mathrm{L}=75 \% \cdot \mathrm{I}=55 \%$ 。宇都 宮はそれぞれ（以下は仙台に海ずる）100\%・55\%・ 20\%・66\%, そして水戸は $66 \% \cdot 51 \% \cdot 50 \% \cdot$ I は0のウェイトとなる。商業はそれぞれの中 心地区Iに高い集積がみられるが，そのらち卸 売業は，後述することく，製造業に次いで拡散 の大きい業種である。

小都市の米沢・白河で汢産業の種類が少なく (第 2 表)，都市域も小さいために，各産業が中心 地区でのウェイトを高めるなど，系統性に欠け る。ただ，米沢は商業 13 社の内 12 が地区 I に，製造業は17 の内 9 （52\%）が地区 II K立 地し, 白河よりは明瞭な地域的分布状態を呈す る。

また，各市において，その分布が地区 II よ り外周に及ぶ産業は、製造業、次いで商業(卸 売業) ・運輸業・建設業等である。製造業は仙 台・水戸では地区 III に，宇都宮は食品工業の 卓越を反映して I および $\mathrm{V}$ ，米沢は II，白河は I・II に分布のピークがみられる。このよらに 製造業の本社が周辺部立地を示す規定的要因 は，前述したことく企業内部に扒いて製造工程 と管理 (本社) 部門が未分化の状態にあるためで ある。そのため, 本社の管理機能だけを中心地 区に設直している例は，仙台などに若干みられ るに過ぎい。各都市の中心地区であるIに製 造業の若干数, 仙台 $10 \cdot$ 宇都宮 $6 \cdot$-水戸1・米 沢 2 ・白河 1 の立地がみられる。その大部分は 本社機能のみのそれではなく、工程部門を併設 した食料品や出版印刷工業である。運輸業は鉄 道駅や幹線道路との関係が強いため，それらの 配置と対応しながら周辺部立地の比重を高め る。また，建設業は水戸を除くと地区 II に分 布のピークがみられ，地区I〜IIIに 100\%の 集中を示す。水戸のそれはIがピークで地区 IVにまたがる。

ところで商業は，各市とも中心地区Iに分布

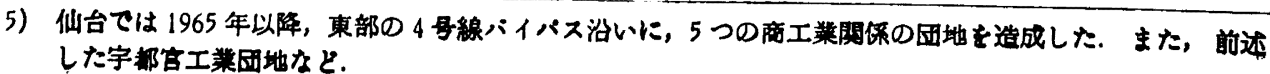


の高い割合がみられ，Iから離れるに従い漸減 するが，いかゆる離心型の業種は自動車・電機 器具・機械等の販売代理店が主体をなす。しか もその多くはかつて中心地区にあり, その後業 務の扗張につれ社屋や敷地が狭险をきたし，転 移した例が压倒的に多い。例えば，仙台の仙塩 街道沿いの苦竹地区に本社を有する自動車ディ 一ラーは 8 社 (筫本金 1 千万円以上) あるが，いず れる19.0 年以降に市街中心地 I から移転した あのである。また，本社のみを創設当時の場所 である中心地に置き，サービスセンター（修理 工場)を移転しているディーラーは 4 社を算 える。しかも興味あることは, 移転時期が遅れ たディーラーほど幹線道路を軸により外周へ分 布している。これらの点は, 上記したことと合 わせて, 宇都宮の上横田地区・水戸の千波地区 でも同様にみられる6)。

（3）資本金階級規模からみた分布の状態

各企業の資本金額を 6 階䄲に分け，それら資 本金階級規模の差異によって，本社はどのよう な地域的分布の態样を示すかを，各市に設定し た単位地区を基に検討してみる。

資本金 1 億円以上の大企業本社の分布を各市 の地区別でみると, 仙台は28 社の内 $\mathrm{I}=18$ ・ $\mathrm{II}=2 \cdot \mathrm{IV}=5 \cdot \mathrm{V}=2 \cdot \mathrm{VII}=1$ で中心地区 I の 割合が全体の $64 \%$ を占める。なかでもIには 資本金階級 $\mathrm{a} ・ \mathrm{~b}$ に属寸る巨大 3 社の分布およ び7業種の集䅡がみられる。それに対し，地区 II ・IV・V・VII はIV の運輸業を除いてはい、 ずれる製造業となっているが，その理由は既述 した。宇都宮・水戸の両市も仙台と似た傾向が みられる。宇都宮には6 社あるが, 地区別では $\mathrm{I}=3 \cdot \mathrm{II}=1 \cdot \mathrm{V}=2$ で 周辺地区立地の製造・ 運輸業を除いては，中心地区 I へ分布してい る。水戸は 5 社で, $5 ち$ 地区 $I=3$, 残る 2 社は それぞれ III およびIV 地区にあり，III のそ れは製造業, IV は運輸業である。米沢は 2 社 で I=1，III=1で III のそれは製造業である。 白河には資本金 1 億円以上の企業本社は存しな い。

このように，大企業本社の分布が必ずしも中 心地区占拁型とならないのは，大企業そのもの の存在が少ないことはもとより，各都市のその
産業構成において、製造業・運輸業など一般に 離心型の業種が比較的多いことによる。すなわ ち，白河を除く4市に批ける大企業（資本金 1 億 円以上)で製造業に属する社数は，仙台 $10 \cdot$ 宇 都宮 2 -水戸 1 ・米沢 1 の合計 14 社。同じく運 輸業は，仙台 $2 \cdot$ 宇都宮 $2 \cdot$ 水戸 1 ・米沢 0 の合 計 5 社となる。そして 44 の製造業の内，その 本社が中心地 I に立地するのは仙台 2 ・宇都宮 1 の僅か 3 社を算えるに過ぎず, 残る 11 社 (79\%)は4市のそれぞれの外周部立地を示す。 また，運輸業は 3 市に 6 社あるが，内 4 社 （66\%）が外周立地となっている。かくて，現業 付属型本社あるいは工場付属型本社 (服部 1964b) 的な企業が大勢を占めるため，業種による分布 の地域的差異はみられても，資本金規模による それの明瞭なパターンは認められない。

\section{3 結言}

各都市内部に扰いて，比較的規模の大きい企 業本社の分布は, 中心地区に高い集積がみられ 中心地区を離れるに従い漸隇する。しかも，都 市規模が大となるにつれて中心地区のウェイト は增すが、このことはＣＢＤとしての機能分化 が進んでいることの一面を示唆する。中心地区 への立地が高い業種は金融・サービス・商業・ 不動産業等であるが、卸売業は幹線道路を軸に かなりの分散を示す。逆に外周部立地のそれ は、製造業・運輸業・建設業等となっており， 大部分の 企業は中心地区立地の 企業と 合わせ て，本社と現業部門が未分化の状態にかる。し かし資本金階級規模による分布の差異について は, 大企業の存立が僅かなため確かな結果は得 られない。したがって今回の調査では，本社は 集在型分布を示すが，それは資本金階級規模に よるより，業種的差異でその地域的分布状態は 異なることが判明したにとどまる。

本稿を作成するに至ったのは，かねて宫城教育大 学田辺健一教授から御覞切な助言をいただいたため であり，心から感謝の意を表する次第てす。 また， 投稿をお靴めいただいた東北大学理学部西村嘉助教 授，御助言をいただいた小笠原節夫助手，並びに現 地調查で御協力いただいた多数の方々にも記して感 謝の意を表します。

(1970. 1. 22 受理)

6）宇都宫の上掼田地区には10社のカーティーラーの本社があるが，うち 8 社が 1958 年以降現在地へ移枟 したるのてある. 水戸の干波地区は，调查した 7 社のディーラーのうち 6 社が旧市街地から現在地へ移 枟した. 


\section{文献}

服部銈二郎 (1964a)：東京における 経济的管理機 能の集中 地理評 37 338 339

（1964 b）：東京における 経斉的管理機 能の漫集と拡散 地域研究 5 3 12

Hoover, E. M., Vernon, R. (1959) : Anatomy of a Metropolis Harvard Univ. Press 98 110

Horwood, E. M., Boyce, R. R. (1959): Studies of the Central Business District and Urban Freeway Development Washington Univ. Press $9 \sim 26$

木内何藏 (1951)：都市地理学研究 古今院 365 $\sim 366$

国民経济研究出会（1967）：首衩東京の都心機能と 本社機能 $81 \sim 171$

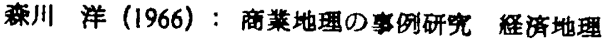
III 大明堂 188

日本道莱海造研究所（1963）：東京都に於ける都心
部の権造と機能の変化に関する調査研究 調查四 季報 No. 16 27 125

（1965）：東京都区部一の人口

及び産業の集中要因に閔する調査研究 309 319

Ogasawara, S. (1966): Recent Changes in and around the Urban Area of Sendai Sci. Repts.

Tohoku Univ. 7th Ser. (Geogr.) 15 117 128 総理府珫計局 (1969)：会社 企邺名籃（昭和 43 年 版)

杉村啺二（1965）：路線価格の地理学的研究一中心 商店待の策華度指数および 業䅂中心地区設定の指 相として一人文地理 $17248 \sim 265$

田辺健一 (1960)：大都市の棈造一地域分化の形成 とその発展一 集落地理講坐 第 2 巻 朝合意店 228〜256

東京市政調查会首都研究所（1964）：第 1部一(1) 機能と幥造からみた東京の範域と受容力205〜216

吉田 宏 (1969)：仙合における支店等事莱所の分

布 東北地理 2145

\section{Distribution of the Head Offices of Firms within Gities}

\section{Hiroshi Yoshida}

There are some investigations on the distribution of the head offices in the metropolis, but no report was available to the writer on medium and small cities. In this paper, the writer gives some comments on the structure of areal distribution of head offices in cities taking examples of five local cities. The subject of study, the head offices of firms, are the campanies with a capital of over 10 million yen, on July 1, 1966.

1. The head offices in each urban area are densely distributed in the center of the city and they are decreasing towards the outer zone, and the weight of head offices is conspicuous in the central district in proportion to the urban scale.

2. Industries concentrated in the central district are finance and insurance, whole sale and retail trade, services, real estate, and so on, but wholesales (car dealers) are dispersed along the trunk roads. zone.

3. There are manufacturing industries, transportations and construction in the outer

4. As the big firms are few, the result was not clear concerning the difference of the areal distribution according to the capital size.

Thus, the head offices of comparatively large scale indicate the centripetal distribution in local medium and small cities, too, but the difference of the areal distribution is great not by the scale of capital but by the kind of the industry. That shows that the controlling function of the head office and field office is not specialized. 